\title{
Gas exchange and organic solutes in forage sorghum genotypes grown under different salinity levels
}

\author{
Daniela S. Coelho ${ }^{1}$, Welson L. Simões ${ }^{2}$, Alessandra M. Salviano ${ }^{2}$, \\ Alessandro C. Mesquita ${ }^{3} \&$ Keila da C. Alberto $^{4}$ \\ ${ }^{1}$ Instituto de Meio Ambiente e Recursos Hídricos/Unidade Regional Sertão do São Francisco. Juazeiro, BA. E-mail: daniela.coelho@hotmail.com.br \\ (Corresponding author) - ORCID: 0000-0003-1125-6960 \\ ${ }^{2}$ Embrapa Semiárido. Petrolina, PE. E-mail: welson.simoes@embrapa.br - ORCID: 0000-0003-1474-9410; alessandra.salviano@embrapa.br - ORCID: \\ 0000-0003-3503-6655 \\ ${ }^{3}$ Universidade do Estado da Bahia/Departamento de Tecnologia e Ciências Sociais. Juazeiro, BA. E-mail: alessandro.mesq@yahoo.com.br - ORCID: \\ 0000-0002-9754-1676 \\ ${ }^{4}$ Universidade de Pernambuco/Departamento de Biologia. Petrolina, PE. E-mail: keiladacosta@hotmail.com - ORCID: 0000-0002-4613-0148
}

\section{Key words:}

salt stress

photosynthesis

chlorophyll

Sorghum bicolor (L.) Moench

\begin{abstract}
A B S T R A C T
Adaptation of plants to saline environments depends on the activation of mechanisms that minimize the effects of excess ions on vital processes, such as photosynthesis. The objective of this study was to evaluate the leaf gas exchange, chlorophyll, and organic solute in ten genotypes of forage sorghum irrigated with solutions of different salinity levels. The experiment was conducted in a randomized block design, in a $10 \times 6$ factorial arrangement, with three replications, using ten genotypes - F305, BRS-655, BRS-610, Volumax, 1.015.045, 1.016.005, 1.016.009, 1.016.013, 1.016.015 and 1.016.031 - and six saline solutions, with electrical conductivity $\left(\mathrm{EC}_{\mathrm{w}}\right)$ of $0,2.5,5.0,7.5,10$ and $12.5 \mathrm{dS} \mathrm{m}^{-1}$. The photosynthetic activity in forage sorghum plants reduces with increasing salinity, and this response was found in the ten genotypes evaluated. The chlorophyll and protein contents were not affected by salinity, whereas carbohydrates and amino acid contents increased with increasing $\mathrm{EC}_{\mathrm{w}}$. Soluble sugars are essential for osmoregulation of forage sorghum due to its high content in leaves.
\end{abstract}

\author{
Palavras-chave: \\ salinidade \\ fotossíntese \\ clorofila \\ Sorghum bicolor (L.) Moench
}

\section{Trocas gasosas e solutos orgânicos em genótipos de sorgo forrageiro sob diferentes níveis de salinidade}

\begin{abstract}
R E S U M O
A adaptação das plantas a ambientes salinos depende da ativação de mecanismos que minimizam os efeitos do excesso de íons sobre processos vitais como a fotossíntese. $\mathrm{O}$ objetivo desse trabalho foi avaliar as trocas gasosas, teores de clorofila e de solutos orgânicos em genótipos de sorgo forrageiro irrigados com soluções de diferentes níveis de salinidade. Utilizou-se o delineamento experimental em blocos casualizados dispostos em esquema fatorial 10 x 6, considerando dez genótipos: 'F305', 'BRS 655', BRS-610, 'Volumax', 1.015.045, $1.016 .005,1.016 .009,1.016 .013,1.016 .015$ e 1.016.031; e soluções com seis valores de condutividade elétrica $\left(\mathrm{CE}_{\mathrm{a}}\right): 0 ; 2,5 ; 5,0 ; 7,5 ; 10$ e 12,5 dS m $\mathrm{m}^{-1}$, utilizando-se três repetições. $\mathrm{O}$ aumento da salinidade influenciou diretamente a redução da atividade fotosintética do sorgo forrageiro, sendo essas respostas semelhantes para os dez genótipos estudados. Os índices de clorofila e teores de proteínas não foram afetados com a salinidade, enquanto que os teores de açúcares solúveis totais, açúcares redutores e aminoácidos foram crescentes com o aumento da $\mathrm{CE}_{\mathrm{a}}$. Devido a sua concentração nas folhas, os açúcares solúveis devem exercer papel predominante na osmorregulação dos genótipos de sorgo forrageiro.
\end{abstract}




\section{INTRODUCTION}

The edaphoclimatic characteristics of the Brazilian semiarid region favor the accumulation of salts in the soil and water sources, causing a stress condition for plants (Medeiros et al., 2010). Plants subjected to salt stress can reduce their photosynthetic rate because of stomatal closure, which limits $\mathrm{CO}_{2}$ availability and interferes in the photosynthetic pigment synthesis, such as chlorophyll (Jamil et al., 2007). This response promotes disturbances on enzyme systems responsible for producing and distributing photosynthetic assimilates (Munns \& Tester, 2008).

Tolerant plants have several biochemical and molecular mechanisms to cope with salt stress, such as synthesis and accumulation of organic compounds-compatible solutes (Parida \& Das, 2005). Compatible solutes are grouped mainly into simple and complex sugars, sugar alcohols, and quaternaries derived from amino acids; accumulations of compatible solutes differ between organisms, even between plant species (Oliveira et al., 2010).

Sorghum bicolor (L) Moench. is a crop species that presents $\mathrm{C}_{4}$ mechanism, and is one of the most versatile and efficient species in terms of photosynthetic mechanism (Berenguer \& Faci, 2001). This contributes to its greater resistance to adverse conditions. The genetic variability of forage sorghum causes different physiological responses to stresses between genotypes. Therefore, the objective of this study was to evaluate the leaf gas exchange, chlorophyll, and organic solute in ten genotypes of forage sorghum irrigated with solutions of different salinity levels.

\section{Material AND Methods}

The experiment was conducted in a greenhouse located in Petrolina, Pernambuco, Brazil (9 9' S, 40 22' W), using ten forage sorghum genotypes-F305, BRS-655, BRS-610, Volumax, 1.015.045, 1.016.005, 1.016.009, 1.016.013, 1.016.015 and 1.016.031. Seeds of the genotypes were sown in $8 \mathrm{~L}$ plastic pots filled with soils sieved in $4 \mathrm{~mm}$ mesh sieves. The drainage was controlled by a layer of approximately two inches of gravel placed at the bottom of the pots, which were perforated and connected to hose collectors. The soil used was classified as Arenic Haplustult, with $84.7 \%$ of sand, $13.5 \%$ of silt, and $1.8 \%$ of clay.

Thinning was performed two weeks after sowing, leaving two plants per pot. Then, the treatments with saline solutions electrical conductivity $\left(\mathrm{EC}_{\mathrm{w}}\right)$ of $0,2.5,5.0,7.5,10$ and $12.5 \mathrm{dS} \mathrm{m}^{-1}$ - were applied. The saline solutions were prepared with $\mathrm{NaCl}$, $\mathrm{CaCl}_{2} \cdot 2 \mathrm{H}_{2} \mathrm{O}$, and $\mathrm{MgSO}_{4} \cdot 7 \mathrm{H}_{2} \mathrm{O}$ salts to obtain the equivalent ratio of 7:2:1 (Na:Ca:Mg) (Aquino et al., 2007). The experiment was conducted in a randomized block design, in a $10 \mathrm{x} 6$ factorial arrangement, with three replications, using ten forage sorghum genotypes and six saline solutions. These solutions were applied manually every two days to maintain the soil moisture close to the field capacity and with a leaching fraction of approximately 0.15 .

A nutrient solution was applied to the soil to correct nutritional lacks, which consisted of $\left(\mathrm{mg} \mathrm{L}^{-1}\right)$ : 160 of $\mathrm{N}, 400$ of P, 210 of K, 180 of S, 0.81 of B, 4.0 of $\mathrm{Zn}, 3.66$ of Mn, 1.33 of $\mathrm{Cu}, 0.15$ of $\mathrm{Mo}$ and 0.10 of Fe (Novais et al., 1999). The nutrients sources were $\left(\mathrm{NH}_{4}\right)_{2} \mathrm{SO}_{4}, \mathrm{NaH}_{2} \mathrm{PO}_{4}, \mathrm{KH}_{2} \mathrm{PO}_{4}, \mathrm{H}_{3} \mathrm{BO}_{3}$, $\mathrm{CuSO}_{4} \cdot 5 \mathrm{H}_{2} \mathrm{O},\left(\mathrm{NH}_{4}\right)_{6} \mathrm{Mo}_{7} \mathrm{O}_{24} \cdot 4 \mathrm{H}_{2} \mathrm{O}, \mathrm{MnSO}_{4} \cdot \mathrm{H}_{2} \mathrm{O}, \mathrm{ZnSO}_{4} \cdot 7 \mathrm{H}_{2} \mathrm{O}$, $\mathrm{FeSO}_{4} .7 \mathrm{H}_{2} \mathrm{O}$ and $\mathrm{Na}_{2} \mathrm{EDTA}$. The nutrient solution was applied after thinning in three times with fifteen-day intervals.

Leaf gas exchange, and chlorophyll $\mathrm{a}$ and $\mathrm{b}$ were measured after 60 days under salt stress, and +3 leaves (third expanded leaf from the apex) were collected and frozen in liquid nitrogen for the further analyses of total soluble sugars, reducing sugars, total free amino acid, and total soluble proteins.

Leaf gas exchange was evaluated using an infrared gas analyzer system (IRGA, Li-6400), in the youngest completely expanded leaf of each plant, under a saturating photosynthetic photon flux density of $1800 \mu \mathrm{mol} \mathrm{m} \mathrm{m}^{-2} \mathrm{~s}^{-1}$. The variables analyzed were photosynthesis (A), stomatal conductance (gs), transpiration (E) and leaf temperature (Tf). Instantaneous water use efficiency (WUE) and intrinsic water use efficiency (IWUE) were assessed from the $\mathrm{A}$ to $\mathrm{E}$ ratio, and $\mathrm{A}$ to gs ratio, respectively. Chlorophyll a and $\mathrm{b}$ were determined from readings in three points of the +3 leaves, using the CFL ClorofiLOG 1030.

Organic solutes were extracted by macerating $0.3 \mathrm{~g}$ of fresh leaf homogenized in $4.0 \mathrm{~mL}$ of phosphate buffer $\left(1.0 \mathrm{~mol} \mathrm{~L}^{-1}, \mathrm{pH}\right.$ 7.0) prepared with potassium dihydrogen phosphate $\left(\mathrm{KH}_{2} \mathrm{PO}_{4}\right)$ and sodium hydrogen phosphate $\left(\mathrm{Na}_{2} \mathrm{HPO}_{4}\right)$ solutions. The material was centrifuged at $2.000 \mathrm{x} \mathrm{g}$, at $23^{\circ} \mathrm{C}$ for $20 \mathrm{~min}$. The supernatant was collected to analyze the total soluble sugars, reducing sugars, total free amino acids, and total soluble proteins.

Soluble sugars were determined according to the Antrona method (Yemm \& Willis, 1954), and reducing sugars were quantified by using 3,5-dinitrosalicylic acid (Miller, 1959). Total free amino acids were determined by the ninhydrin assay (Yemm \& Coccking, 1955), and total soluble proteins were quantified according to the Bradford's method (Bradford, 1976).

The data were subjected to analysis of variance using the Sisvar 5.0 program. When the $\mathrm{EC}_{\mathrm{w}}$ factor was significant, the data were subjected to regression models and tested at $1 \%$ probability (t test). The Scott Knott test at $5 \%$ probability was used to compare the genotypes.

\section{Results AND Discussion}

The analysis of variance showed no significant interactions between genotypes and salinity effects, which allows an independent analysis of these factors. Irrigation with salinity solution caused significant effect on leaf gas exchange and leaf organic solute contents, but did not affect the chlorophyll $\mathrm{a}$ and $\mathrm{b}$ contents in the forage sorghum genotypes evaluated. The genotypes showed similar results of net photosynthesis (A) regardless of the salinity level (Table 1), except F305, which showed the lowest A.

The lowest net photosynthesis of the genotype F305 might be related to its limitation in stomatal opening, as shown by lower stomatal conductance (gs), which caused low water loss through the transpiration process. The stomatal closure is an 
Table 1. Physiological analysis of leaves of ten forage sorghum genotypes subjected to different salinity levels

\begin{tabular}{lcccccc}
\hline Genotypes & $\begin{array}{c}\text { A } \\
\left(\mu \mathbf{m o l ~ m}^{-2} \mathbf{~ s}^{-1}\right)\end{array}$ & $\begin{array}{c}\text { gs } \\
\left(\mathbf{m o l ~ m}^{-2} \mathbf{~ s}^{-1}\right)\end{array}$ & $\begin{array}{c}\mathbf{E} \\
\left(\mathbf{m m o l ~ m}^{-2} \mathbf{~ s}^{-1}\right)\end{array}$ & $\begin{array}{c}\text { Tf } \\
\left({ }^{\circ} \mathbf{C}\right)\end{array}$ & WUE & IWUE \\
F305 & $16.0 \mathrm{~b}$ & $0.061 \mathrm{~b}$ & $1.57 \mathrm{c}$ & $31.8 \mathrm{a}$ & $9.7 \mathrm{a}$ & $258.6 \mathrm{a}$ \\
BRS-655 & $27.8 \mathrm{a}$ & $0.158 \mathrm{a}$ & $3.41 \mathrm{a}$ & $31.5 \mathrm{~b}$ & $8.8 \mathrm{a}$ & $202.2 \mathrm{a}$ \\
BRS-610 & $29.3 \mathrm{a}$ & $0.150 \mathrm{a}$ & $3.18 \mathrm{a}$ & $31.3 \mathrm{~b}$ & $9.2 \mathrm{a}$ & $207.0 \mathrm{a}$ \\
Volumax & $25.0 \mathrm{a}$ & $0.116 \mathrm{~b}$ & $2.64 \mathrm{~b}$ & $31.6 \mathrm{a}$ & $10.8 \mathrm{a}$ & $264.1 \mathrm{a}$ \\
1.015 .045 & $28.1 \mathrm{a}$ & $0.179 \mathrm{a}$ & $3.56 \mathrm{a}$ & $31.3 \mathrm{~b}$ & $8.3 \mathrm{a}$ & $186.5 \mathrm{a}$ \\
1.016 .005 & $22.0 \mathrm{a}$ & $0.097 \mathrm{~b}$ & $2.21 \mathrm{~b}$ & $31.6 \mathrm{a}$ & $12.3 \mathrm{a}$ & $315.8 \mathrm{a}$ \\
1.016 .009 & $23.8 \mathrm{a}$ & $0.111 \mathrm{~b}$ & $2.53 \mathrm{~b}$ & $31.8 \mathrm{a}$ & $9.7 \mathrm{a}$ & $240.9 \mathrm{a}$ \\
1.016 .013 & $26.5 \mathrm{a}$ & $0.136 \mathrm{~b}$ & $2.88 \mathrm{~b}$ & $31.6 \mathrm{a}$ & $10.7 \mathrm{a}$ & $262.7 \mathrm{a}$ \\
1.016 .015 & $23.9 \mathrm{a}$ & $0.110 \mathrm{~b}$ & $2.46 \mathrm{~b}$ & $31.7 \mathrm{a}$ & $11.1 \mathrm{a}$ & $280.6 \mathrm{a}$ \\
1.016 .031 & $26.3 \mathrm{a}$ & $0.127 \mathrm{~b}$ & $2.81 \mathrm{~b}$ & $31.7 \mathrm{a}$ & $12.3 \mathrm{a}$ & $312.1 \mathrm{a}$ \\
\hline
\end{tabular}

$\mathrm{A}=$ Net photosynthesis; gs = Stomatal conductance; $\mathrm{E}=$ Transpiration; $\mathrm{Tf}=$ Leaf temperature; WUE = Instantaneous water use efficiency; IWUE = Intrinsic water use efficiency. Means followed by the same letter in the columns do not differ by the Scott Knott test at 0.05 probability

adaptive mechanism of plants to prevent excessive loss of water, especially under stress conditions (Wang et al., 2016). However, this mechanism affects the photosynthetic activity, and limits the entry of $\mathrm{CO}_{2}$ through stomatal pores; this may cause a reduction in the photoassimilate production, affecting growth and productivity, as already observed in sorghum-sudangrass crops (Feijão et al., 2011).

The average photosynthesis found in the genotypes, except F305, was close to that commonly found for forage sorghum. Miranda et al. (2013) found photosynthesis rates of 25 to 35 $\mu \mathrm{mol} \mathrm{m} \mathrm{m}^{2}$ in forage sorghum, and no significant changes in these rates after application of $75 \mathrm{mM}$ salt solutions for three and seven days were observed. Kakani et al. (2011) found photosynthesis rates of 35 to $45 \mu \mathrm{mol} \mathrm{m}{ }^{2} \mathrm{~s}^{-1}$ in grains of sorghum
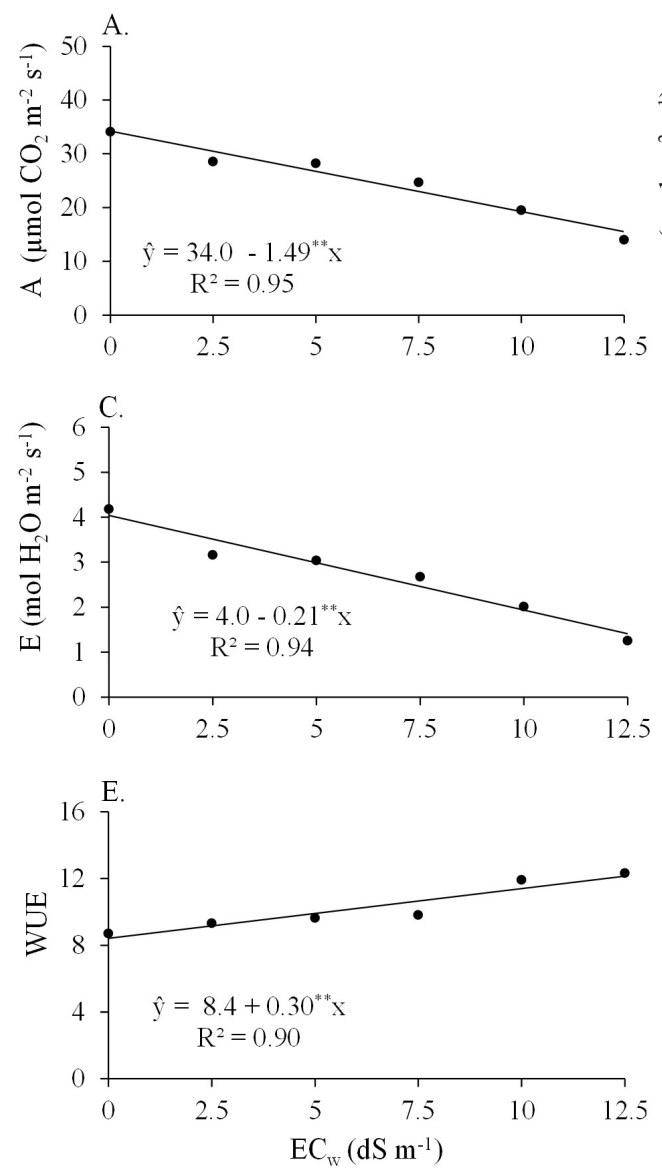

Regression ** significant at 0.01 probability ( $t$ test)

Figure 1. $A=$ Photosynthesis rate $(A)$, gs $=$ Stomatal conductance $(B), E=$ Transpiration $(C)$, Tf $=$ Leaf temperature (D), WUE = Instantaneous water use efficiency (E), and IWUE = Intrinsic water use efficiency (F) in different sorghum genotypes, after 60 days of irrigation with saline solutions of different electrical conductivity levels plants that were not subjected to environmental stresses. Similar result was found by Xie \& Su (2012), who evaluated sweet sorghum leaves in peak radiation hours, and under non-apparent stress.

The BRS-655, BRS-610 and 1.015.045 genotypes had higher stomatal conductance (gs), which promoted higher transpiration rates (E), and consequently lower leaf temperature (Tf). However, the higher gs of these genotypes were not followed by a significant increase in photosynthesis. Although the genotypes had differences in A, gs, and E, they had similar results of instantaneous water use efficiency (WUE), and intrinsic water use efficiency (IWUE).

Regarding the effect of salinity on gas exchange, the A, gs, and $\mathrm{E}$ had linear reductions with increasing $\mathrm{EC}_{\mathrm{w}}$ (Figure 1).
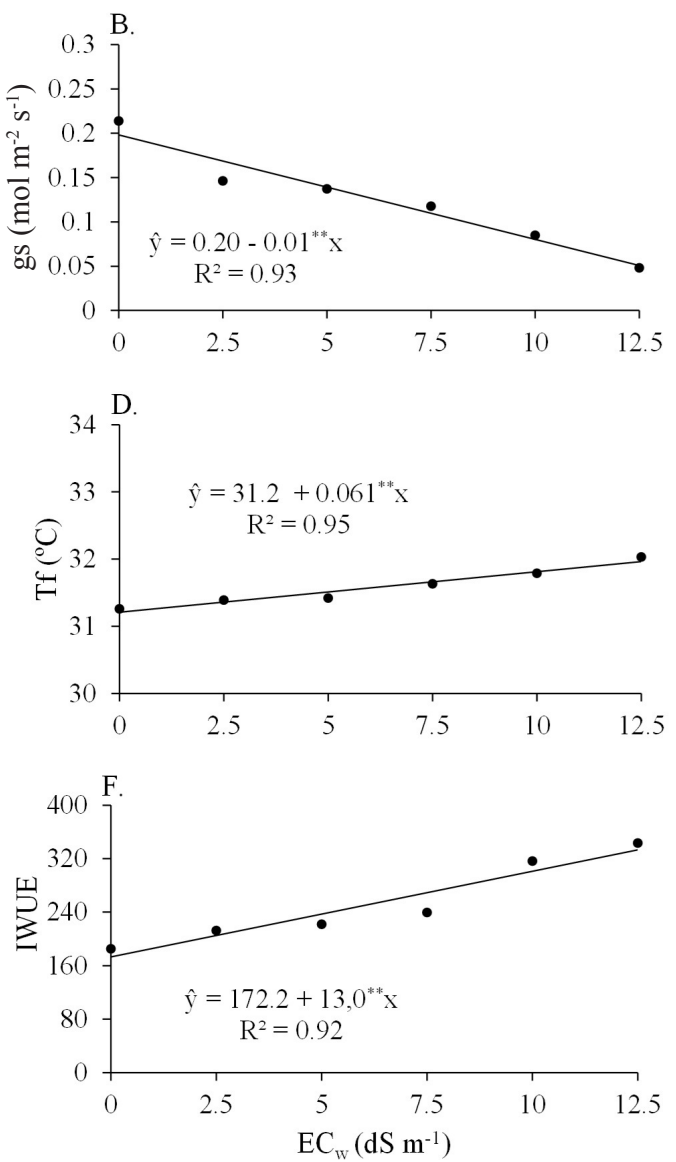
Long exposure to salts causes changes in the plant water status, stomatal closure and, consequently, limitation of mesophyll conductance to $\mathrm{CO}_{2}$ (Silva et al., 2011). Moreover, high concentrations of ions, such as $\mathrm{Na}^{+}$and $\mathrm{Cl}$, have been reported as the cause of damage to enzyme and membrane structures, affecting directly the photosynthesis. Reductions of gs with consequent reductions of A and $\mathrm{E}$ were also found in Jatropha curcas (Sousa et al., 2012) and common beans (Souza et al., 2011).

The A (Figure 1A), gs (Figure 1B) and E (Figure 1C) reduced with salinity, and the Tf (Figura 1D), WUE (Figure 1E) and IWUE (Figure $1 \mathrm{~F}$ ) increased gradually with increasing $\mathrm{EC}_{\mathrm{w}}$. This denotes the ability of this crop to adapt to saline stress and maintain a positive photosynthesis rate, even under conditions that limits water absorption.

This response may be related to the $\mathrm{C}_{4}$ metabolism of forage sorghum plants, which results in high rates of photosynthesis under conditions of temporary reduction in the availability of $\mathrm{CO}_{2}$ caused by stomatal closure (Taiz \& Zeiger, 2013). Fernandes et al. (2010) reported that plants with high WUE might present high tolerance to salinity due to their great water loss control, and reduction of the toxic ion flow to plant shoot after limiting transpiration.

Different chlorophyll a and $\mathrm{b}$ contents were found only between genotypes (Figure 2), denoting that this variable is intrinsic to each genotype, and not related to the salt effects on the plants. Different results were found by Lacerda et al. (2003), who evaluated two fodder sorghum varieties.

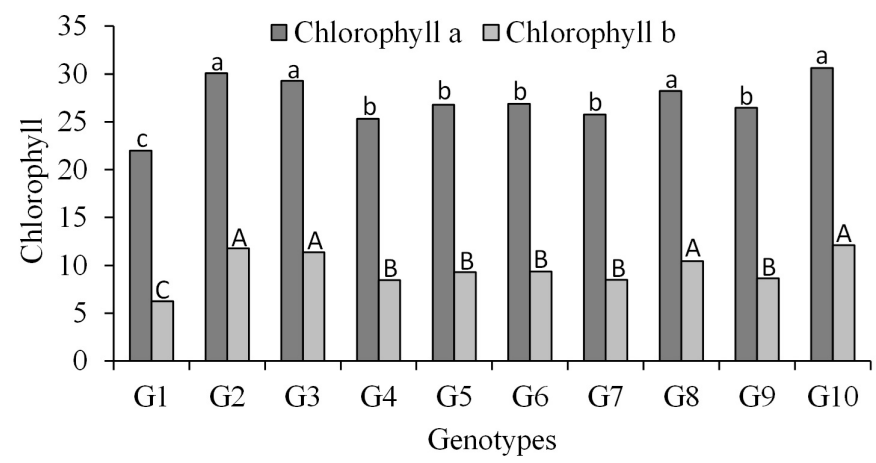

Bars with the same lowercase letters for chlorophyll a content, and the same uppercase letters for chlorophyll b content do not differ among genotypes by the Scott Knott test at $5 \%$ probability Figure 2. Chlorophyll a and b contents in leaves of ten forage sorghum genotypes - F305 (G1), BRS-655 (G2), BRS-610 (G3), Volumax (G4), 1.015.045 (G5), 1.016.005 (G6), 1.016.009 (G7), 1.016.013 (G8), 1.016 .015 (G9) and 1.016.031 (G10)
The BRS-655, BRS-610, 1.016.013 and 1.016.031 genotypes presented the highest chlorophyll $\mathrm{a}$ and $\mathrm{b}$ contents. The lowest content of this variable was found in the F305 genotype, which had also the lowest photosynthesis. Priori et al. (2003) also found correlation between chlorophyll content and photosynthetic activity. Chlorophyll a and $\mathrm{b}$ contents make chlorophyll-protein complexes, which are important for the regulation and organization of photosystems, and essential for production of the chemical energy used in photoassimilate synthesis (Morais et al., 2007).

The salinity levels evaluated did not affect the chlorophyll $a$ and $b$ contents. This may indicate an adaptive mechanism of this species to prevent degradation of these pigments caused by the effect of toxic ions, such as $\mathrm{Na}^{+}$and $\mathrm{Cl}$. Jamil et al. (2007) stated that salinity reduces the chlorophyll content in plants susceptible to salt stress, and increases chlorophyll content in plants tolerant to salt stress. Graciano et al. (2011) found increments in chlorophyll content in peanut leaves with increasing salinity levels, thus increasing photosynthetic efficiency, and attributed this result to a compensatory mechanism of the plant that maintain its growth and production.

Reducing sugars, and amino acids concentration had gradual increases with increasing salinity levels, regardless of the genotype (Figure 3). Leaf soluble sugar concentration also increased linearly, regardless of the genotype; however, the linear regression showed low coefficient of determination $\left(\hat{y}=30.0+1.17^{* *} \mathrm{x}, \mathrm{R}^{2}=0.50\right)$. Changes in total soluble protein concentration were not found under these same conditions.

The comparison between the highest and lowest salinity levels showed increases of $106 \%$ for reducing sugars, $67 \%$ for soluble sugar, and $129 \%$ for amino acids. However, when an absolute increase of these solutes in the leaves was observed, the soluble sugars predominated over the others. Similarly, Lacerda et al. (2001) found high soluble sugar concentrations in forage sorghum genotypes subjected to salinity, which confirms the importance of soluble sugars for the osmotic regulation of leaf cells in this species.

Nonreducing sugars were predominant in the soluble sugar concentration, denoting their probable osmoregulatory function in forage sorghum leaves. Bezerra et al. (2003) reported that the photosynthetic activity is less sensitive to saline stress than the growth, generating an extra production of assimilates, which are not immediately used by the plant and
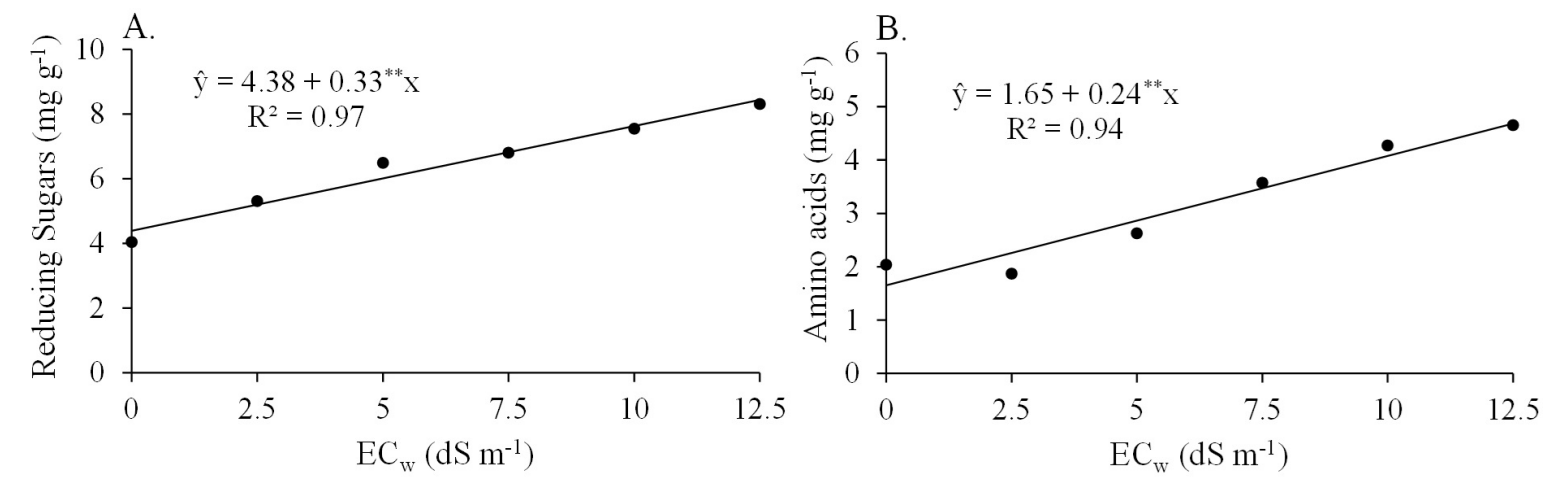

Regression ** Significant at 0.01 probability (t test)

Figure 3. Reducing sugars, and amino acids concentration in leaves of forage sorghum plants of different genotypes, after 60 days of irrigation with saline solutions of different electrical conductivity levels 
are accumulated as a compatible solute. Paul \& Foyer (2001) stated that the breakdown of starch due to increased amylase activity in the leaf cells results in the release of soluble sugars.

Different from the soluble sugars, the increase in total amino acids concentration with increasing salinity was greater than that of the other organic solutes, however, this increase was not enough to show its capacity of osmoregulation in leaf cells; thus, its function may be linked to the protection of cellular structures (Munns, 2005). The increase in leaf amino acids concentration with increasing salinity levels was also reported by Feijão et al. (2011), who evaluated sorghumsudangrass, and Lacerda et al. (2001), who studied two forage sorghum genotypes. Moreover, these salinity effects on soluble protein concentration in forage sorghum leaves differed from those found by Sadeghi \& Shourijeh (2012), with significant increases with increasing salinity levels.

\section{Conclusions}

1. The photosynthetic activity in forage sorghum plants reduces with increasing salinity, and this response was found in the ten genotypes evaluated.

2. Chlorophyll contents in the leaves of the genotypes evaluated was not affect by the salinity levels used.

3. Concentration of soluble sugars, especially nonreducing sugars, are essential for the osmoregulation in forage sorghum leaves.

\section{Literature Cited}

Aquino, A. J. S. de; Lacerda, C. F. de; Bezerra, M. A.; Gomes Filho, E.; Costa, R. N. T. Crescimento, partição de matéria seca e retenção de $\mathrm{Na}^{+}, \mathrm{K}^{+}$e $\mathrm{Cl}^{-}$em dois genótipos de sorgo irrigados com águas salinas. Revista Brasileira de Ciência do Solo, v.31, p.961-971, 2007. https://doi.org/10.1590/S0100-06832007000500013

Berenguer, M. J.; Faci, J. M. Sorghum (Sorghum bicolor L. Moench) yield compensation processes under different plant densities and variable water supply. European Journal of Agronomy, v.15, p.43-55, 2001. https://doi.org/10.1016/S1161-0301(01)00095-8

Bezerra, M. A.; Oliveira, R. A. de; Lacerda, C. F. de; Prisco, J. T.; Gomes-Filho, E. Fotossíntese de plantas de cajueiro-anão precoce submetidas ao estresse salino. Proceedings of the Interamerican Society for Tropical Horticulture, v.47, p.149-152, 2003.

Bradford, M. M. A rapid and sensitive method for the quantitation of microgram quantities of protein utilizing the principle of protein-dye binding. Analytical Biochemistry, v.72, p.248-254, 1976. https://doi.org/10.1016/0003-2697(76)90527-3

Feijão, A. R.; Silva, J. C. B. da; Marques, E. C.; Prisco, J. T.; GomesFilho, E. Efeito da nutrição de nitrato na tolerância de plantas de sorgo sudão à salinidade. Revista Ciência Agronômica, v.42, p.675-683, 2011. https://doi.org/10.1590/S180666902011000300014

Fernandes, P. D.; Gheyi, H. R.; Andrade, A. P.; Medeiros, S. S. Biossalinidade e produção agrícola. In: Gheyi, H. R.; Dias, N. S.; Lacerda, C. F. (ed.) Manejo da salinidade na agricultura: Estudos básicos e aplicados. Fortaleza: Instituto Nacional de Ciência e Tecnologia em Salinidade, 2010. Cap.12, p.303-317.
Graciano, E. S. A.; Nogueira, R. J. M. C.; Lima, D. R. M.; Pacheco, C. M.; Santos. R. C. Crescimento e capacidade fotossintética da cultivar de amendoim BR 1 sob condições de salinidade. Revista Brasileira de Engenharia Agrícola e Ambiental, v.15, p.794-800, 2011. https://doi.org/10.1590/S1415-43662011000800005

Jamil, M.; Rehman, S. ur; Lee, K. J.; Kim, J. M.; Kim, H. S.; Rha, E. S. Salinity reduced growth PS2 photochemistry and chlorophyll content in radish. Scientia Agricola, v.64, p.111-118, 2007. https://doi.org/10.1590/S0103-90162007000200002

Kakani, V. G.; Vu, J. C. V.; Allen Júnior, L. H.; Boote, K. J. Leaf photosynthesis and carbohydrates of $\mathrm{CO}_{2}$-enriched maize and grain sorghum exposed to a short period of soil water deficit during vegetative development. Journal of Plant Physiology, v.168, p.2169-2176, 2011. https://doi.org/10.1016/j.jplph.2011.07.003

Lacerda, C. F. de; Cambraia, J.; Cano, M. A. O.; Ruiz, H. A. Plant gowth and solute accumulation and distribution in two sorghum genotypes, under $\mathrm{NaCl}$ stress. Revista Brasileira de Fisiologia Vegetal, v.13, p.270-284, 2001. https://doi.org/10.1590/S010331312001000300003

Lacerda, C. F. de; Cambraia, J.; Cano, M. A. O.; Ruiz, H. A.; Prisco, J. T. Solute accumulation and distribution during shoot and leaf development in two sorghum genotypes under salt stress. Environmental and Experimental Botany, v.49, p.107-120, 2003. https://doi.org/10.1016/S0098-8472(02)00064-3

Medeiros, J. F.; Nascimento, I. B.; Gheyi, H. R. Estratégias de manejo para uso de água salina na agricultura. In: Gheyi, H. R.; Dias, N. S.; Lacerda, C. F. (ed.) Manejo da salinidade na agricultura: Estudos básicos e aplicados. Fortaleza: Instituto Nacional de Ciência e Tecnologia em Salinidade, 2010. Cap.17, p.303-317.

Miller, G. L. Use of dinitrosalicylic acid reagent for determination of reducing sugar. Analytical Chemistry, v.31, p.426-428, 1959. https://doi.org/10.1021/ac60147a030

Miranda, R. de S.; Alvarez-Pizarro, J. C.; Araújo, C. M. S.; Prisco, J. T.; Gomes-Filho, E. Influence of inorganic nitrogen sources on $\mathrm{K}^{+} / \mathrm{Na}^{+}$homeostasis and salt tolerance in sorghum plants. Acta Physiologiae Plantarum, v.35, p.841-852, 2013. https://doi. org/10.1007/s11738-012-1128-2

Morais, R. R. de; Gonçalves, J. F. de C.; Santos Júnior, U. M. dos; Dünisch, O.; Santos, A. L. W dos. Chloroplastid pigment contents and chlorophyll a fluorescence in amazonian tropical three species. Revista Árvore, v.31, p.959-966, 2007. https://doi. org/10.1590/S0100-67622007000500020

Munns, R. Genes and salt tolerance: Bringing them together. New Phytologist, v.167, p.45-663, 2005. https://doi.org/10.1111/j.14698137.2005.01487.x

Munns, R.; Tester, M. Mechanisms of salinity tolerance. Annual Review of Plant Biology, v.59, p.651-681, 2008. https://doi. org/10.1146/annurev.arplant.59.032607.092911

Novais, R. F.; Neves, J. C. L.; Barros, N. F. Ensaios em ambiente controlado. In: Oliveira, A. J. (org.). Métodos de pesquisa em fertilidade do solo. 1.ed. Brasília: EMBRAPA-SEA, 1991. Cap.2, p.89-253.

Oliveira, A. B. de; Gomes-Filho, E.; Enéas Filho, J. O problema da salinidade na agricultura e as adaptações das plantas ao estresse salino. Enciclopédia Biosfera, v.6, p.1-16, 2010.

Parida, A. K.; Das, A. B. Salt tolerance and salinity effects on plants: A review. Ecotoxicology and Environmental Safety, v.60, p.324-349, 2005. https://doi.org/10.1016/j.ecoenv.2004.06.010 
Paul, M. J.; Foyer, C. H. Sink regulation for photosynthesis. Journal of Experimental Botany, v.52, p.1383-1400, 2001. https://doi. org/10.1093/jexbot/52.360.1383

Priori, L. D.; Eamus, D.; Bownan, D. M. J. S. Leaf attributes in the seasonally dry tropics: A comparison of four habitats in northen Australia. Functional Ecology, v.1, p.504-515, 2003. https://doi. org/10.1046/j.1365-2435.2003.00761.x

Sadeghi, H.; Shourijeh, F. A. Salinity induced effects on growth parameters, chemical and biochemical characteristics of two forage sorghum (Sorghum bicolor L.) cultivars. Asian Journal of Plant Sciences, v.11, p.19-27, 2012. https://doi.org/10.3923/ ajps.2012.19.27

Silva, E. N. da; Ribeiro, R. V.; Silva, S. L. F.; Viégas, R. A.; Silveira, J. A. G. Salt stress induced damages on the photosynthesis of physic nut young plants. Scientia Agricola, v.68, p.62-68, 2011. https:// doi.org/10.1590/S0103-90162011000100010

Sousa, A. E. C.; Silveira, J. A. G.; Gheyi, H. R.; Lima Neto, M. C.; Lacerda, C. F. de; Soares, F. A. L. Trocas gasosas e conteúdo de carboidratos e compostos nitrogenados em pinhão-manso irrigado com águas residuária e salina. Pesquisa Agropecuária Brasileira, v.47, p.14281435, 2012. https://doi.org/10.1590/S0100-204X2012001000003
Souza, R. P.; Machado, E. C.; Silveira, J. A. G.; Ribeiro, R. V. Fotossíntese e acúmulo de solutos em feijoeiro caupi submetido à salinidade. Pesquisa Agropecuária Brasileira, v.46, p.586-592, 2011. https://doi.org/10.1590/S0100-204X2011000600003

Taiz, L.; Zeiger, E. Fisiologia vegetal. 5.ed. Porto Alegre: ArtMed, 2013. 954p.

Wang, W.-H; He, E.-M; Guo, Y; Tong, Q.-X; Zheng, H.-L. Chloroplast calcium and ROS signaling networks potentially facilitate the primed state for stomatal closure under multiple stresses. Envionmental and Experimental Botany, v.122, p.85-93, 2016. https://doi.org/10.1016/j.envexpbot.2015.09.008

Xie, T.; Su, P. Canopy and leaf photosynthetic characteristics and water use efficiency of sweet sorghum under drought stress. Russian Journal of Plant Physiology, v.59, p.224-234, 2012. https://doi. org/10.1134/S1021443712020197

Yemm, E. W.; Cocking, E. C. The determination of aminoacid with ninhydrin. Analyst, v.80, p.209-213, 1955. https://doi.org/10.1039/ an9558000209

Yemm, E. W.; Willis, A. J. The estimation of carbohydrates in plants extracts by anthrone. Biochemical Journal, v.57, p.508-514, 1954. https://doi.org/10.1042/bj0570508 